\title{
Metabolome of Mammary Tumors Differs from Normal Mammary Glands But Is Not Altered by Time-restricted Feeding Under Obesogenic Conditions
}

\author{
LIN YAN, SNEHA SUNDARAM, BRET M. RUST, MATTHEW J. PICKLO and MICHAEL R. BUKOWSKI \\ U.S. Department of Agriculture, Agricultural Research Service, Grand \\ Forks Human Nutrition Research Center, Grand Forks, ND, U.S.A.
}

\begin{abstract}
Background/Aim: Time restricted feeding (TRF) mitigates the high-fat diet-enhanced mammary tumorigenesis in a MMTV-PyMT breast cancer model. Materials and Methods: We performed untargeted metabolomic and targeted transcriptomic analyses on mammary tumors from MMTVPyMT mice fed a standard AIN93G diet, a high-fat diet (HFD), or HFD with TRF (12 h, dark phase) and mammary glands from wild-type mice fed the AIN93G diet. Results: The metabolic profile of mammary tumors differed from that of mammary glands; there was no impact of TRF upon tumor metabolome. TRF did reduce elevated expression of $\mathrm{Hmgcr}$, Srebp1, Fads2, and Ppard in mammary tumors, indicating a down-regulation of lipid metabolism. Conclusion: The null effect of TRF on the metabolomic profile does not rule out changes in more refined intracellular signaling pathways. It suggests that the protection of TRF against mammary tumorigenesis may rely upon its action on the host rather than a direct effect on tumor metabolism.
\end{abstract}

Breast cancer is a commonly diagnosed cancer and a leading cause of cancer-related death in women worldwide (1). It remains an area of active research both clinically and experimentally. Recent advances in metabolomics show that metabolic profiling can be useful for identification of biomarkers in breast cancer. Metabolic profiles of human breast cancer show differences among breast cancer subtypes

This article is freely accessible online.

Correspondence to: Lin Yan, Ph.D., USDA, ARS, Grand Forks Human Nutrition Research Center, $24202^{\text {nd }}$ Avenue North, Grand Forks, ND 58203, U.S.A. Tel: +1 7017958499, Fax: +1 7017958220,e-mail: Lin.Yan@usda.gov

Key Words: Metabolomics, mammary tumor, MMTV-PyMT, highfat diet, mice. and offer a way to identify and develop strategies for precise prevention and treatment (2-4).

Obesity is a risk factor for breast cancer; its occurrence is positively associated with the risk of breast cancer $(5,6)$. Obesity is a modern disorder that has resulted, not just from changes in energy balance, but from changes in lifestyle that alter meal times and eating patterns $(7,8)$. These changes, as environmental factors, disrupt biological rhythms and contribute to metabolic dysfunction $(9,10)$. Laboratory studies have shown that the feeding timing modifies obesogenesis in rodents. For example, mice fed a high-fat diet (HFD) during the light phase (rest phase for nocturnal animals) gain more weight than mice fed during the dark phase (active phase for nocturnal animals) (11). Mice fed a HFD during both light and dark phases exhibit altered daily pattern of energy expenditure and gain body fat (12). Time-restricted feeding (TRF) is an effective tool in obesity research in rodents. It reinforces the circadian rhythms of energy metabolism by temporal regulation of the feeding/fasting pattern to a fixed time during the dark phase of the day. Available studies have shown that TRF restores the diurnal rhythms of energy metabolism (12) and circadian gene expression (13), improves insulin sensitivity, and reduces body adiposity and inflammation in mice fed a HFD (12-14).

In our research into interactions of diet and breast cancer prevention, we found that TRF (12 hours, dark phase) mitigates the HFD-enhanced mammary tumorigenesis in the mouse mammary tumor virus-polyoma middle $\mathrm{T}$ antigen (MMTV-PyMT) model. Tumorigenesis in the MMTV-PyMT model is spontaneous; its progression is characterized as hyperplasia, adenoma, neoplasia, and carcinoma with high incidence of pulmonary metastasis $(15,16)$. The MMTVPyMT tumors exhibit luminal B tumor signature including short latency and high penetrance $(17,18)$. With the goal of determining the metabolic profile of MMTV-PyMT mammary tumors and its changes by dietary intervention, we performed metabolomic analysis and assessed genes encoding proteins involved in lipid metabolism on mammary tumors from a 
Table I. Identified metabolites related to lipid metabolism that differ between wild-type mice fed the AIN93G control diet (AIN93G Ctl) and MMTVPyMT mice fed the AIN93G diet (AIN93G MMTV), the high-fat diet (HFD MMTV), or time-restricted feeding of the HFD (TRF MMTV).

\begin{tabular}{|c|c|c|c|c|c|}
\hline Metabolic pathway & Metabolites & AIN93G Ctl & AIN93G MMTV & HFD MMTV & TRF MMTV \\
\hline Lipids & $\begin{array}{l}\text { Palmitic acid } \\
\text { Oleic acid } \\
\text { Stearic acid } \\
\text { Myristic acid } \\
\text { Linoleic acid } \\
\text { Palmitoleic acid } \\
\text { Heptadecanoic acid } \\
\text { Pentadecanoic acid } \\
\text { 3-Hydroxybutyric acid } \\
\text { 2-Monoolein } \\
\text { Cholesterol } \\
\text { Fumaric acid } \\
\text { Malic acid } \\
\text { Oxalic acid } \\
\text { Ethanolamine } \\
\text { Phosphoethanolamine } \\
\text { Methanol phosphate } \\
\text { Phosphate }\end{array}$ & $\begin{array}{l}1.00 \pm 0.09^{\mathrm{a}} \\
1.00 \pm 0.12^{\mathrm{a}} \\
1.00 \pm 0.08^{\mathrm{a}} \\
1.00 \pm 0.11^{\mathrm{a}} \\
1.00 \pm 0.11^{\mathrm{a}} \\
1.00 \pm 0.13^{\mathrm{a}} \\
1.00 \pm 0.10^{\mathrm{a}} \\
1.00 \pm 0.11^{\mathrm{a}} \\
1.00 \pm 0.12^{\mathrm{ab}} \\
1.00 \pm 0.07^{\mathrm{b}} \\
1.00 \pm 0.07^{\mathrm{b}} \\
1.00 \pm 0.09^{\mathrm{b}} \\
1.00 \pm 0.10^{\mathrm{b}} \\
1.00 \pm 0.10^{\mathrm{b}} \\
1.00 \pm 0.08^{\mathrm{b}} \\
1.00 \pm 0.13^{\mathrm{b}} \\
1.00 \pm 0.06^{\mathrm{b}} \\
1.00 \pm 0.10^{\mathrm{b}}\end{array}$ & $\begin{array}{l}0.37 \pm 0.04^{\mathrm{b}} \\
0.17 \pm 0.06^{\mathrm{b}} \\
0.40 \pm 0.04^{\mathrm{b}} \\
0.30 \pm 0.05^{\mathrm{b}} \\
0.22 \pm 0.05^{\mathrm{b}} \\
0.31 \pm 0.06^{\mathrm{b}} \\
0.41 \pm 0.04^{\mathrm{b}} \\
0.70 \pm 0.08^{\mathrm{b}} \\
1.58 \pm 0.24^{\mathrm{a}} \\
2.05 \pm 0.19^{\mathrm{ab}} \\
1.23 \pm 0.05^{\mathrm{a}} \\
2.55 \pm 0.12^{\mathrm{a}} \\
3.53 \pm 0.22^{\mathrm{a}} \\
1.62 \pm 0.12^{\mathrm{a}} \\
1.55 \pm 0.10^{\mathrm{a}} \\
3.39 \pm 0.33^{\mathrm{a}} \\
1.67 \pm 0.08^{\mathrm{a}} \\
1.32 \pm 0.06^{\mathrm{a}}\end{array}$ & $\begin{array}{l}0.32 \pm 0.02^{\mathrm{b}} \\
0.09 \pm 0.03^{\mathrm{b}} \\
0.41 \pm 0.03^{\mathrm{b}} \\
0.23 \pm 0.03^{\mathrm{b}} \\
0.23 \pm 0.04^{\mathrm{b}} \\
0.17 \pm 0.03^{\mathrm{b}} \\
0.45 \pm 0.02^{\mathrm{b}} \\
0.60 \pm 0.04^{\mathrm{b}} \\
1.14 \pm 0.20^{\mathrm{a}} \\
3.17 \pm 0.52^{\mathrm{a}} \\
1.45 \pm 0.15^{\mathrm{a}} \\
2.33 \pm 0.16^{\mathrm{a}} \\
3.80 \pm 0.31^{\mathrm{a}} \\
1.34 \pm 0.14^{\mathrm{ab}} \\
1.45 \pm 0.09^{\mathrm{a}} \\
2.74 \pm 0.37^{\mathrm{a}} \\
1.61 \pm 0.13^{\mathrm{a}} \\
1.20 \pm 0.05^{\mathrm{ab}}\end{array}$ & $\begin{array}{l}0.29 \pm 0.04^{\mathrm{b}} \\
0.09 \pm 0.04^{\mathrm{b}} \\
0.35 \pm 0.03^{\mathrm{b}} \\
0.20 \pm 0.03^{\mathrm{b}} \\
0.24 \pm 0.05^{\mathrm{b}} \\
0.13 \pm 0.03^{\mathrm{b}} \\
0.41 \pm 0.05^{\mathrm{b}} \\
0.55 \pm 0.04^{\mathrm{b}} \\
0.50 \pm 0.08^{\mathrm{b}} \\
2.45 \pm 0.29^{\mathrm{a}} \\
1.31 \pm 0.08^{\mathrm{a}} \\
2.54 \pm 0.21^{\mathrm{a}} \\
3.79 \pm 0.25^{\mathrm{a}} \\
1.17 \pm 0.12^{\mathrm{b}} \\
1.36 \pm 0.06^{\mathrm{a}} \\
3.14 \pm 0.35^{\mathrm{a}} \\
1.36 \pm 0.14^{\mathrm{ab}} \\
1.13 \pm 0.03^{\mathrm{a}}\end{array}$ \\
\hline
\end{tabular}

Values (means \pm SEM) in the same row with different letters are significant at $p<0.05$ ( $\mathrm{n}=12$ each for AIN93G Ctl and AIN93G MMTV groups; $\mathrm{n}=13$ each for HFD MMTV and TRF MMTV groups).

study showing that TRF reduces the HFD-enhanced mammary tumorigenesis in MMTV-PyMT mice (19).

\section{Materials and Methods}

Animals and diets. The Grand Forks Human Nutrition Research Center vivarium provided MMTV-PyMT mice (FVB background) for this study (19). The breeding colony was established by using FVB/NJ females (stock no. 001800) and hemizygous FVB/NTg(MMTV-PyMT)634Mul/J males (stock no. 002374) from The Jackson Laboratory (Bar Harbor, ME, USA). Mice were maintained in a pathogen-free room on a $12 / 12$-h light/dark cycle at $22 \pm 1^{\circ} \mathrm{C}$. Mice were housed two per cage to avoid stress related to single housing and weighed weekly. The standard AIN93G diet providing $16 \%$ of energy from soybean oil (20) and a modified AIN93G diet providing $45 \%$ energy from soybean oil (hereafter referred to as the high-fat diet, HFD) (19) were used in this study.

Experimental design. The Institutional Animal Care and Use Committee of the Grand Forks Human Nutrition Research Center approved this study (Project no. YAN027). The study was conducted in compliance with the guide for the care and use of laboratory animals by the National Institutes of Health (21).

The experimental design has been previously reported (19). Briefly, three-week-old female MMTV-PyMT mice were weaned onto the AIN93G diet $(\mathrm{n}=40)$ or the HFD $(\mathrm{n}=80)$ ad libitum. One week later, mice fed the HFD were split into two groups of 40 each. One group was provided HFD ad libitum for both light and dark phases; the other group had the diet restricted to the dark phase (12 h) between Zeitgeber times 12 and 24 (hereafter referred to as timerestricted feeding, TRF). The duration of the restricted feeding was eight weeks. Additional age-matched female FVB/NJ mice were fed the AIN93G diet and served as wild-type controls. Their mammary glands were used for the comparison of metabolomic changes to mammary tumors from MMTV-PyMT mice. Following the restricted feeding, mice were palpated for mammary tumors twice weekly (19). Palpable tumors were measured weekly for tumor growth (19). At the end of the study, mice were euthanized by an intraperitoneal injection of a mixture of ketamine and xylazine. Mammary glands from wild-type mice and mammary tumors from MMTV-PyMT mice (both were from thoracic, abdominal, and inguinal locations) were collected and stored at $-80^{\circ} \mathrm{C}$.

Mammary metabolomics. Metabolomic analysis (22, 23) was performed at the West Coast Metabolomics Center (University of California-Davis, Davis, CA, USA). Briefly, mammary glands and mammary tumors were homogenized and extracted with the acetonitrile/isopropanol/ $\mathrm{H}_{2} \mathrm{O}(3: 3: 2)$ buffer, resuspended in a diluted acetonitrile solution (acetonitrile $/ \mathrm{H}_{2} \mathrm{O}, 1: 1$ ), and analyzed by gas chromatography time-of-flight mass spectrometry (GC-TOF-MS) for untargeted metabolomics of primary metabolism. Data were processed by using the BinBase database (24). For identified metabolites, quantifier ion peak heights were normalized to the sum intensities of all known compounds. Metabolites representing less than $0.02 \%$ of total signal intensity were excluded from statistical analyses.

RNA isolation and real-time quantitative PCR. Total RNA from frozen mammary glands and mammary tumors was isolated by using the QIAzol Lysis reagent with DNAse treatment following the protocol from RNeasy Lipid Tissue Mini Kit mRNA (Qiagen, Germantown, MD, USA). The quality and quantity of the RNA were analyzed by using the NanoDrop 8000 spectrophotometer (Thermo Scientific, Wilmington, DE, USA). cDNA was synthesized 
Yan et al: Metabolome of Mammary Tumors and Obesity

Table II. Identified metabolites related to protein metabolism that differ between wild-type mice fed the AIN93G control diet (AIN93G Ctl) and MMTV-PyMT mice fed the AIN93G diet (AIN93G MMTV), the high-fat diet (HFD MMTV), or time-restricted feeding of the HFD (TRF MMTV).

\begin{tabular}{|c|c|c|c|c|c|}
\hline Metabolic pathway & Metabolites & AIN93G Ctl & AIN93G MMTV & HFD MMTV & TRF MMTV \\
\hline Proteins & $\begin{array}{l}\text { Glutamic acid } \\
\text { Aspartic acid } \\
\text { Glutamine } \\
\text { Glycine } \\
\text { Alanine } \\
\text { Serine } \\
\text { Threonine } \\
\text { Cysteine } \\
\text { Methionine } \\
\text { Asparagine } \\
\text { Histidine } \\
\text { Tyrosine } \\
\text { Tryptophan } \\
\text { Leucine } \\
\text { Proline } \\
\text { Cystine } \\
\beta \text {-alanine } \\
\text { Ornithine } \\
\text { trans-4-hydroxyl-L-proline } \\
\text { Cyanoalanine } \\
\text { Oxoproline } \\
\text { Aminomalonate }\end{array}$ & $\begin{array}{l}1.00 \pm 0.10^{\mathrm{b}} \\
1.00 \pm 0.08^{\mathrm{b}} \\
1.00 \pm 0.08^{\mathrm{b}} \\
1.00 \pm 0.04^{\mathrm{b}} \\
1.00 \pm 0.09^{\mathrm{b}} \\
1.00 \pm 0.06^{\mathrm{b}} \\
1.00 \pm 0.04^{\mathrm{b}} \\
1.00 \pm 0.10^{\mathrm{b}} \\
1.00 \pm 0.08^{\mathrm{b}} \\
1.00 \pm 0.12^{\mathrm{b}} \\
1.00 \pm 0.10^{\mathrm{b}} \\
1.00 \pm 0.05^{\mathrm{b}} \\
1.00 \pm 0.05^{\mathrm{b}} \\
1.00 \pm 0.06^{\mathrm{b}} \\
1.00 \pm 0.22^{\mathrm{b}} \\
1.00 \pm 0.17^{\mathrm{b}} \\
1.00 \pm 0.11^{\mathrm{b}} \\
1.00 \pm 0.10^{\mathrm{b}} \\
1.00 \pm 0.12^{\mathrm{b}} \\
1.00 \pm 0.10^{\mathrm{b}} \\
1.00 \pm 0.07^{\mathrm{b}} \\
1.00 \pm 0.12^{\mathrm{b}}\end{array}$ & $\begin{array}{l}3.32 \pm 0.17^{\mathrm{a}} \\
1.69 \pm 0.10^{\mathrm{a}} \\
2.30 \pm 0.17^{\mathrm{a}} \\
2.21 \pm 0.12^{\mathrm{a}} \\
1.45 \pm 0.10^{\mathrm{a}} \\
1.87 \pm 0.08^{\mathrm{a}} \\
1.36 \pm 0.06^{\mathrm{a}} \\
4.63 \pm 0.42^{\mathrm{a}} \\
1.87 \pm 0.23^{\mathrm{a}} \\
2.88 \pm 0.36^{\mathrm{a}} \\
1.53 \pm 0.25^{\mathrm{ab}} \\
1.52 \pm 0.08^{\mathrm{a}} \\
1.34 \pm 0.08^{\mathrm{a}} \\
1.53 \pm 0.15^{\mathrm{a}} \\
2.65 \pm 0.68^{\mathrm{ab}} \\
3.74 \pm 0.37^{\mathrm{a}} \\
2.80 \pm 0.42^{\mathrm{a}} \\
1.41 \pm 0.11^{\mathrm{ab}} \\
1.65 \pm 0.17^{\mathrm{ab}} \\
1.33 \pm 0.07^{\mathrm{ab}} \\
1.86 \pm 0.11^{\mathrm{a}} \\
3.29 \pm 0.20^{\mathrm{a}}\end{array}$ & $\begin{array}{l}3.14 \pm 0.20^{\mathrm{a}} \\
1.74 \pm 0.09^{\mathrm{a}} \\
2.23 \pm 0.26^{\mathrm{a}} \\
2.33 \pm 0.13^{\mathrm{a}} \\
1.55 \pm 0.12^{\mathrm{a}} \\
1.86 \pm 0.11^{\mathrm{a}} \\
1.38 \pm 0.07^{\mathrm{a}} \\
4.36 \pm 0.48^{\mathrm{a}} \\
1.75 \pm 0.17^{\mathrm{a}} \\
2.98 \pm 0.37^{\mathrm{a}} \\
1.87 \pm 0.29^{\mathrm{a}} \\
1.57 \pm 0.11^{\mathrm{a}} \\
1.38 \pm 0.09^{\mathrm{a}} \\
1.47 \pm 0.13^{\mathrm{a}} \\
3.37 \pm 0.69^{\mathrm{a}} \\
3.76 \pm 0.26^{\mathrm{a}} \\
3.54 \pm 0.48^{\mathrm{a}} \\
1.55 \pm 0.15^{\mathrm{a}} \\
1.98 \pm 0.26^{\mathrm{ab}} \\
1.30 \pm 0.09^{\mathrm{ab}} \\
1.73 \pm 0.09^{\mathrm{a}} \\
3.37 \pm 0.33^{\mathrm{a}}\end{array}$ & $\begin{array}{l}3.54 \pm 0.22^{\mathrm{a}} \\
2.06 \pm 0.13^{\mathrm{a}} \\
2.50 \pm 0.28^{\mathrm{a}} \\
2.40 \pm 0.12^{\mathrm{a}} \\
1.51 \pm 0.08^{\mathrm{a}} \\
2.12 \pm 0.08^{\mathrm{a}} \\
1.54 \pm 0.06^{\mathrm{a}} \\
5.59 \pm 0.58^{\mathrm{a}} \\
1.93 \pm 0.16^{\mathrm{a}} \\
3.39 \pm 0.28^{\mathrm{a}} \\
1.77 \pm 0.12^{\mathrm{ab}} \\
1.66 \pm 0.10^{\mathrm{a}} \\
1.34 \pm 0.09^{\mathrm{a}} \\
1.41 \pm 0.05^{\mathrm{a}} \\
2.71 \pm 0.37^{\mathrm{ab}} \\
4.57 \pm 0.50^{\mathrm{a}} \\
3.74 \pm 0.51^{\mathrm{a}} \\
1.77 \pm 0.17^{\mathrm{a}} \\
2.71 \pm 0.54^{\mathrm{a}} \\
1.37 \pm 0.10^{\mathrm{a}} \\
1.94 \pm 0.09^{\mathrm{a}} \\
3.38 \pm 0.30^{\mathrm{a}}\end{array}$ \\
\hline
\end{tabular}

Values (means \pm SEM) in the same row with different letters are significant at $p<0.05$ ( $\mathrm{n}=12$ each for AIN93G Ctl and AIN93G MMTV groups; $\mathrm{n}=13$ each for HFD MMTV and TRF MMTV groups).

by using the high capacity cDNA reverse transcription kit (Applied Biosystems, Waltham, MA, USA). Real-time qPCR was performed for acetyl-CoA carboxylase (Acaca) (Mm01304257_m1), fatty acid synthase (Fasn) (Mm00662319_m1), fatty acid desaturase (Fads) 1 (Mm00507605_m1) and 2 (Mm00517221_m1), HMG-CoA reductase (Hmgcr) (Mm01281499_m1), peroxisome proliferatoractivated receptors (Ppar) Ppara (Mm00440939_m1), Ppard (Mm01305434_m1), and Pparg (Mm00440940_m1), stearoyl-CoA desaturase 1 (Scd1) (Mm00772290_m1), and sterol regulatory element-binding protein 1 (Srebfl) (Mm00550338_m1). The expression of these genes was normalized to the 18s rRNA (Mm03928990_g1) by using the TaqMan Assay of Demand primers on the ABI QuantStudio 12K-Flex Real-time PCR system (Applied Biosystems). The $2^{-\Delta \Delta C T}$ method was used to calculate the relative changes in gene expression (25).

Statistical analysis. Metabolomic data were analyzed by using MetaboAnalyst software (version 3.0, McGill University, Sainte Anne de Bellevue, Quebec, Canada) (26,27). Data were normalized by the Pareto scaling method and analyzed by sparse partial least squares-discriminant analysis (sPLSDA) $(26,27)$. The false discovery rate-corrected $p$-values were reported (26). Results (means \pm standard error of the mean) from MMTV-PyMT groups are presented as fold changes in comparison to the wild-type control group fed the AIN93G diet. Differences in expression of genes encoding proteins involved in lipid metabolism among the four groups were compared by using one-way analysis of variance and Tukey contrasts (SAS software, version 9.4, SAS Institute, Cary, NC, USA). Differences with a $p \leq 0.05$ are considered significant.

\section{Results}

A total of 94 metabolites were identified from 412 discrete signals detected in mammary glands from wild-type mice and mammary tumors from MMTV-PyMT mice by using the GC-TOF-MS. After adjustment for the false discovery rate, 50 metabolites differed significantly among the four dietary groups (Tables I-III).

The sPLSDA visualized the group separations and individual sample variability and identified the metabolites under these separations (Figure 1). Component 1 separated the dietary groups into two categories, 1) wild-type control mice fed the AIN93G diet and 2) MMTV-PyMT mice, regardless of dietary treatment (Figure 1A). The loadings plot for component 1 identified glycerol, the amino acids glutamic acid and glycine, and the fatty acids palmitic acid, oleic acid, stearic acid, myristic acid, malic acid, palmitoleic acid, and linoleic acid as major determinants of separation (Figure 1C).

Component 2 separated the AIN93G-fed MMTV-PyMT group from the remaining three dietary groups (Figure 1A). The loading plot for component 2 identified 3hydroxybutyric acid, $\gamma$-tocopherol, oxalic acid, sorbitol, phosphate, methanolphosphate, myristoleic acid, trans-4hydroxy-L-proline, ethanolamine, and urea as major determinants of separation (Figure 1D). 
Table III. Identified metabolites related to nucleoside, sugar, and vitamin metabolism that differ between wild-type mice fed the AIN93G control diet (AIN93G Ctl) and MMTV-PyMT mice fed the AIN93G diet (AIN93G MMTV), the high-fat diet (HFD MMTV), or time-restricted feeding of the HFD (TRF MMTV).

\begin{tabular}{|c|c|c|c|c|c|}
\hline Metabolic pathways & Metabolites & AIN93G Ctl & AIN93G MMTV & HFD MMTV & TRF MMTV \\
\hline \multirow[t]{4}{*}{ Nucleosides } & Uric acid & $1.00 \pm 0.12^{\mathrm{b}}$ & $2.92 \pm 0.25^{\mathrm{a}}$ & $3.04 \pm 0.29^{\mathrm{a}}$ & $3.21 \pm 0.28^{\mathrm{a}}$ \\
\hline & Uracil & $1.00 \pm 0.09^{\mathrm{b}}$ & $2.09 \pm 0.09^{\mathrm{a}}$ & $2.45 \pm 0.20^{\mathrm{a}}$ & $2.44 \pm 0.26^{\mathrm{a}}$ \\
\hline & Uridine & $1.00 \pm 0.10^{\mathrm{b}}$ & $2.76 \pm 0.28^{\mathrm{a}}$ & $2.50 \pm 0.21^{\mathrm{a}}$ & $2.87 \pm 0.22^{\mathrm{a}}$ \\
\hline & Pseudo uridine & $1.00 \pm 0.06^{\mathrm{b}}$ & $1.32 \pm 0.08 \mathrm{a}^{\mathrm{b}}$ & $2.03 \pm 0.29^{\mathrm{a}}$ & $1.42 \pm 0.26^{\mathrm{ab}}$ \\
\hline \multirow[t]{4}{*}{ Sugars } & Glucose & $1.00 \pm 0.13^{\mathrm{a}}$ & $0.29 \pm 0.10^{\mathrm{b}}$ & $0.35 \pm 0.06^{\mathrm{b}}$ & $0.37 \pm 0.06^{\mathrm{b}}$ \\
\hline & Glycerol & $1.00 \pm 0.07^{\mathrm{a}}$ & $0.42 \pm 0.05^{\mathrm{b}}$ & $0.34 \pm 0.03^{b}$ & $0.34 \pm 0.03^{b}$ \\
\hline & Glycerol- $\alpha$-phosphate & $1.00 \pm 0.13^{b}$ & $5.12 \pm 0.45^{\mathrm{a}}$ & $4.62 \pm 0.35^{\mathrm{a}}$ & $5.20 \pm 0.44^{\mathrm{a}}$ \\
\hline & $\beta$-Glycerol-phosphate & $1.00 \pm 0.10^{\mathrm{b}}$ & $2.19 \pm 0.21^{\mathrm{a}}$ & $2.28 \pm 0.16^{\mathrm{a}}$ & $2.23 \pm 0.10^{\mathrm{a}}$ \\
\hline \multirow[t]{2}{*}{ Vitamins } & $\gamma$-Tocopherol & $1.00 \pm 0.15^{\mathrm{a}}$ & $0.61 \pm 0.06^{\mathrm{b}}$ & $1.00 \pm 0.07^{\mathrm{a}}$ & $1.08 \pm 0.08^{\mathrm{a}}$ \\
\hline & Pantothenic acid & $1.00 \pm 0.12^{b}$ & $1.87 \pm 0.21^{\mathrm{a}}$ & $1.64 \pm 0.15^{\mathrm{a}}$ & $1.71 \pm 0.12^{\mathrm{a}}$ \\
\hline
\end{tabular}

Values (means \pm SEM) in the same row with different letters are significant at $p<0.05$ ( $\mathrm{n}=12$ each for AIN93G Ctl and AIN93G MMTV groups; $\mathrm{n}=13$ each for HFD MMTV and TRF MMTV groups).

Component 3 separated the HFD-fed MMTV-PyMT group from the other three dietary groups (Figure 1B). The loading plot for component 3 identified succinate semialdehyde, pseudo uridine, behenic acid, 2-monoolein, thymidine, 3phenyllactic acid, arachidonic acid, cholesterol, Nacetylaspartic acid, and $\alpha$-tocopherol as major determinants of separation (Figure 1E).

Tables I-III show the 50 metabolites that differed significantly among the four groups. Forty-three of them differed between mammary glands from wild-type mice and mammary tumors from MMTV-PyMT mice (Tables I-III). Of these, 30 were higher in mammary tumors than in mammary glands. These included four essential amino acids (threonine, methionine, leucine, and tryptophan), 12 non-essential amino acids including glutamine, glycine, and serine, and uridine and its nucleobase uracil (Tables I-III). Eleven metabolites were lower in mammary tumors including glucose, glycerol, $\gamma$-tocopherol, and mid-chain and long-chain fatty acids (Tables I-III). In MMTV-PyMT mice, metabolic profiles of mammary tumors between the groups fed the AIN93G diet and HFD were similar (Tables I-III), except the HFD restored $\gamma$-tocopherol in mammary tumors compared to the AIN93G diet (Table III). Metabolic profiles of mammary tumors from the TRF group were similar to that from the HFD group, except 3-hydroxybutyric acid was 56\% lower in the TRF group than in the HFD group (Table I).

The expression of genes encoding proteins involved in lipid metabolism in mammary tumors differed from that in mammary glands. In mice fed the AIN93G diet, the expression of Fads1, Fads2, Srebf1, Hmgcr, and Ppard was higher, ranging from $140 \%$ to $310 \%$, in mammary tumors than in mammary glands (Table IV). The expression of Fasn, Scd1, Ppara, and Pparg was approximately 90\% lower in mammary tumors (Table IV). In MMTV-PyMT mice, there was no difference in gene expression between the groups fed the AIN93G diet and the HFD (Table IV). Compared to the HFD, TRF lowered the expression of Srebfl by $32 \%$ and Hmgcr by $41 \%$ (Table IV). Furthermore, the expression of Fads2 and Ppard of the TRF group was $29 \%$ and 36\%, respectively, lower than that of the AIN93G-fed MMTVPyMT group (Table IV).

\section{Discussion}

Mammary tumorigenesis in MMTV-PyMT mice is spontaneous and aggressive. All MMTV-PyMT mice develop palpable mammary tumors at six to seven weeks of age, regardless of diet (19). In the current study, non-targeted metabolomic analysis of mammary tumors from MMTVPyMT mice and mammary glands from wild-type mice identified a total of 94 metabolites, of which 50 differed among the four groups. These differences in metabolomic profiles, along with difference in expression of genes encoding proteins involved in lipid metabolism, indicate accelerated, disordered metabolism in mammary tumors, which supports the aggressiveness of the malignancy $(19,28)$.

Mammary tumors from MMTV-PyMT mice exhibited disrupted lipid metabolism. Elevations in phosphoethanolamine and its precursor ethanolamine, as well as lower concentrations of free fatty acids (both saturated and unsaturated), in mammary tumors indicate an altered phospholipid synthesis in mammary tumor cells. Phosphoethanolamine is a major phospholipid component; highly proliferative cancer cells activate phospholipid synthesis to generate new membrane $(29,30)$. Our findings are consistent with in vitro studies showing that MCF7 (31) and MDA-MB-231 breast cancer cells (32) exhibit elevated phosphoethanolamine. The notion of accelerated phospholipid synthesis in mammary tumors is further supported 


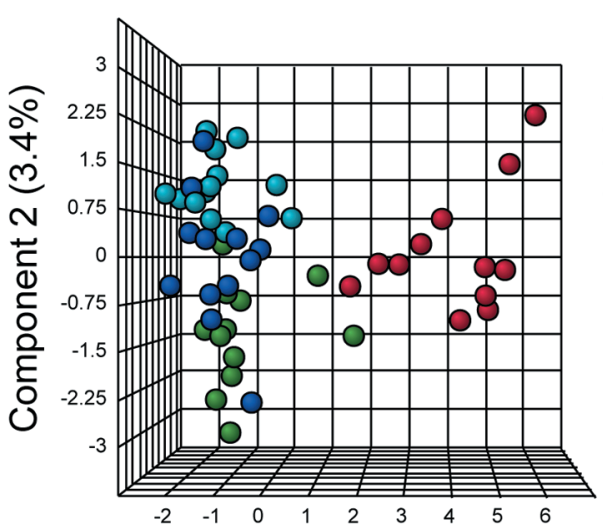

Component $1(28.7 \%)$
AIN93G CtI - AIN93G MMTV OHFD MMTV OTRF MMTV

\section{A}
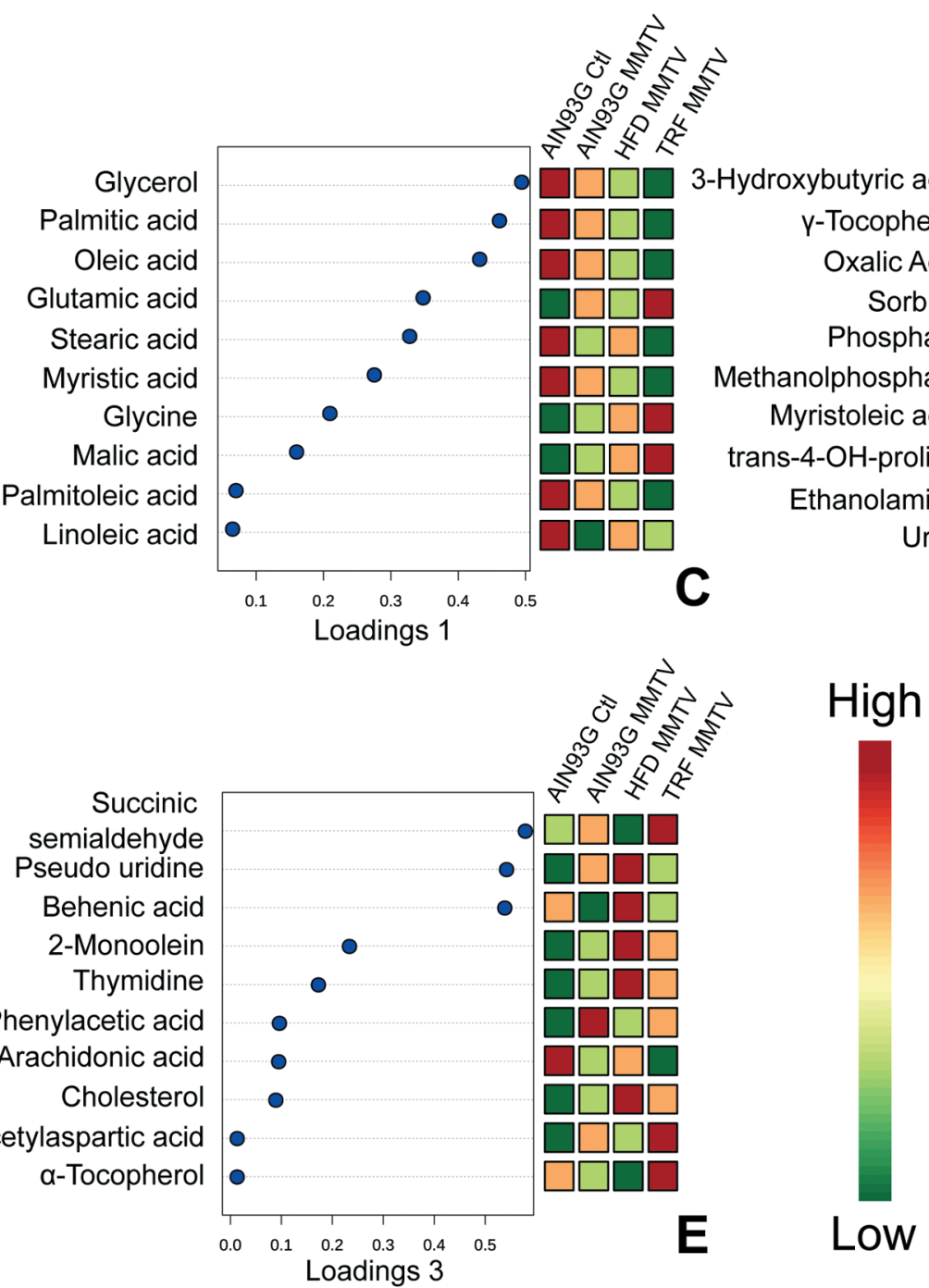

High

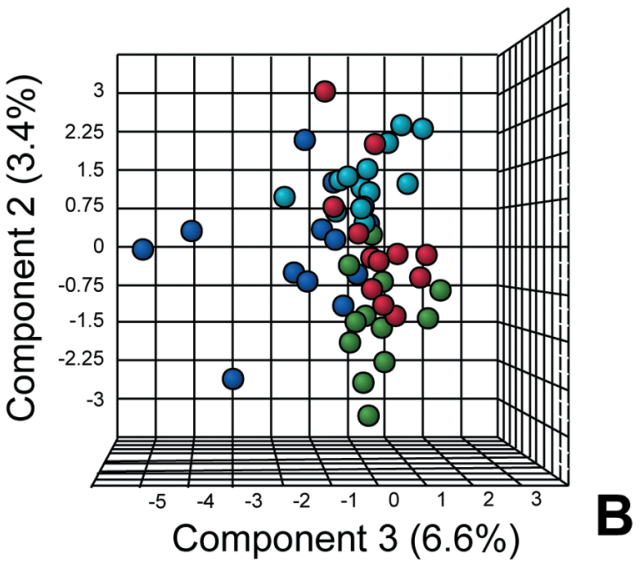

Component 3 (6.6\%)
B
Methanolphosphate

Myristoleic acid

trans-4-OH-proline

Ethanolamine

Urea

.

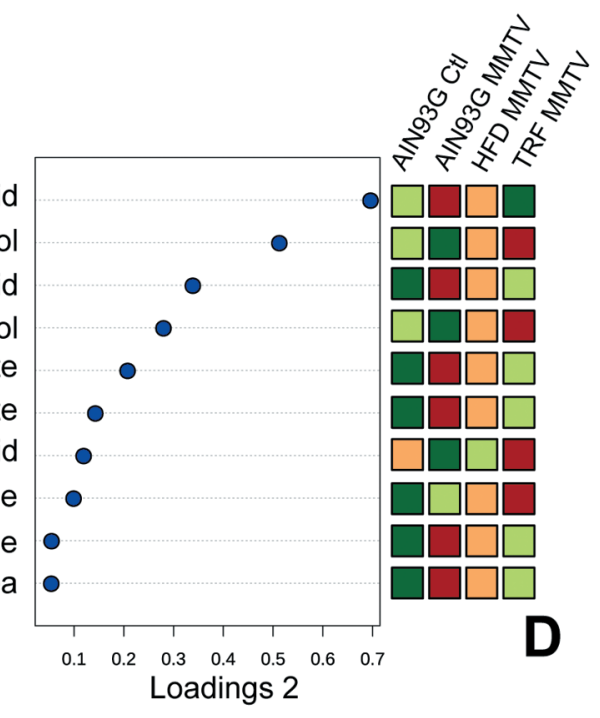

Loadings 2

Figure 1. Sparse Partial Least Square Discriminant Analysis-synchronized three-dimensional plots of the four dietary groups (A and B) and loading plots of 10 metabolites that are most influential in treatment separation among the four groups for components 1,2, and $3(C, D$, and E). A: Components 1 vs. 2; B: Components 2 vs. 3. AIN93G Ctl (red): mammary glands from wild-type mice fed the AIN93G control diet; AIN93G MMTV (green): mammary tumors from MMTV-PyMT mice fed the AIN93G diet; HFD MMTV (blue): mammary tumors from MMTV-PyMT mice fed the HFD; TRF MMTV (cyan): mammary tumors from MMTV-PyMT mice with time-restricted feeding of the HFD. N=12 each for AIN93G Ctl and AIN93G MMTV groups; $n=13$ each for HFD MMTV and TRF MMTV groups. 
Table IV. Expression of genes encoding proteins involved in lipid metabolism in mammary glands from wild-type mice fed the AIN93G control diet (AIN93G Ctl) and MMTV-PyMT mice fed the AIN93G diet (AIN93G MMTV), the high-fat diet (HFD MMTV), or time-restricted feeding of the HFD (TRF MMTV).

\begin{tabular}{|c|c|c|c|c|}
\hline mRNA & AIN93G Ctl & AIN93G MMTV & HFD MMTV & TRF MMTV \\
\hline Acaca & $1.00 \pm 0.18^{\mathrm{a}}$ & $0.66 \pm 0.11^{\mathrm{ab}}$ & $0.30 \pm 0.03^{b c}$ & $0.25 \pm 0.04^{\mathrm{c}}$ \\
\hline Fasn & $1.00 \pm 0.23^{\mathrm{a}}$ & $0.12 \pm 0.02^{\mathrm{b}}$ & $0.05 \pm 0.01^{\mathrm{b}}$ & $0.05 \pm 0.01^{\mathrm{b}}$ \\
\hline Fads1 & $1.00 \pm 0.16^{\mathrm{b}}$ & $3.81 \pm 0.44^{\mathrm{a}}$ & $3.97 \pm 0.48^{\mathrm{a}}$ & $2.98 \pm 0.46^{\mathrm{a}}$ \\
\hline Fads2 & $1.00 \pm 0.20^{\mathrm{c}}$ & $2.83 \pm 0.19^{\mathrm{a}}$ & $2.59 \pm 0.18^{\mathrm{ab}}$ & $2.00 \pm 0.24^{b}$ \\
\hline$S c d 1$ & $1.00 \pm 0.18^{\mathrm{a}}$ & $0.15 \pm 0.04^{b}$ & $0.08 \pm 0.02^{\mathrm{b}}$ & $0.04 \pm 0.01^{b}$ \\
\hline Srebf1 & $1.00 \pm 0.15^{\mathrm{c}}$ & $4.13 \pm 0.38^{\mathrm{a}}$ & $3.55 \pm 0.27^{\mathrm{a}}$ & $2.40 \pm 0.28^{b}$ \\
\hline $\mathrm{Hmgcr}$ & $1.00 \pm 0.12^{\mathrm{c}}$ & $3.23 \pm 0.33^{\mathrm{ab}}$ & $3.85 \pm 0.35^{\mathrm{a}}$ & $2.29 \pm 0.29^{b}$ \\
\hline Ppara & $1.00 \pm 0.18^{\mathrm{a}}$ & $0.12 \pm 0.04^{\mathrm{b}}$ & $0.05 \pm 0.03^{b}$ & $0.05 \pm 0.02^{b}$ \\
\hline Ppard & $1.00 \pm 0.09^{\mathrm{c}}$ & $2.38 \pm 0.25^{\mathrm{a}}$ & $2.06 \pm 0.18^{\mathrm{ab}}$ & $1.53 \pm 0.19^{\mathrm{bc}}$ \\
\hline Pparg & $1.00 \pm 0.18^{\mathrm{a}}$ & $0.09 \pm 0.03^{b}$ & $0.03 \pm 0.01^{\mathrm{b}}$ & $0.05 \pm 0.01^{b}$ \\
\hline
\end{tabular}

Values (means $\pm \mathrm{SEM}$ ) in the same row with different letters are significant at $p<0.05$ ( $\mathrm{n}=12$ per group).

by clinical observations that phosphoethanolamine in breast cancer specimen is linearly elevated with Ki-67, a marker of cell proliferation (33). Moreover, decreased free fatty acids have been found in breast cancer tissues compared to normal breast tissues (34).

Cholesterol is essential for membrane biogenesis. It is also an obligatory precursor of steroid hormone synthesis (e.g. estrogen) for tumorigenesis. We found high concentrations of cholesterol in mammary tumors from MMTV-PyMT mice, particularly those fed the HFD. The MMTV-PyMT mice fed the HFD have larger mammary tumors than their AIN93Gfed counterparts (19). The elevation in cholesterol is supported by elevated expression of Hmgcr and Srebpl (genes that encode rate-limiting enzymes for cholesterol and lipid synthesis) in mammary tumors. Our findings are further supported by the reports that hypercholesterolemia promotes mammary tumorigenesis and invasiveness in MMTV-PyMT mice $(35,36)$.

Mammary tumorigenesis in MMTV-PyMT mice likely accelerated protein synthesis. This is evidenced by elevations in amino acids (both essential and nonessential) in mammary tumors. For example, glutamine serves as a carbon donor and a nitrogen donor for amino acid and nucleotide synthesis (37). Increased demands for ATP and lipids are essential for rapidly proliferating cancer cells (37). Metabolism of glycine and serine (38) and of branched chain amino acids (e.g. leucine) (39) play important roles in cancer metabolic phenotype and cancer environment. Glycine and serine are biosynthetically connected and are necessary for synthesis of proteins, lipids, and nucleic acids to be used in cellular proliferation. Elevated glycine in cancer biopsies is associated with lower survival rates in estrogen receptor positive breast cancer patients (38). Dietary glycine and serine restriction reduce tumorigenesis in rodent models of lymphoma and intestinal cancer (40). Furthermore, our findings that uridine and its nucleobase uracil were higher in mammary tumors suggest an upregulation of RNA translation. It supports the notion of accelerated protein synthesis in MMTV-PyMT mammary tumors.

MMTV-PyMT tumorigenesis may have accelerated glucose metabolism, evidenced by lower concentrations of glucose and an increase in glycerol-3-phophase, a glycolysis intermediate, in mammary tumors. This is an indication of aerobic glycolysis, defined as the Warburg Effect in cancer metabolism (41). Furthermore, the aforementioned elevations in amino acids in mammary tumors support the notion of disturbed glucose metabolism during MMTV-PyMT tumorigenesis. Elevated amino acids in blood have been a characteristic of impaired glucose metabolism (42).

Ppard participates in regulation of lipid and glucose metabolism in multiple cell types (43). The elevated expression of Ppard in mammary tumors indicates that Ppard may play a role in metabolism during MMTV-PyMT mammary tumorigenesis. It suggests the possibility of an increase in fatty acid $\beta$-oxidation, evidenced by reduced free fatty acids in mammary tumors. This is further supported by lower expression of Fasn and Acaca (genes that encode proteins involved in de novo lipogenesis of saturated fatty acid palmitic acid) and Scdl (the gene that controls the synthesis of unsaturated fatty acids oleic acid and palmitoleic acid) in mammary tumors. Moreover, Ppard has been considered, in some studies, to be an oncogene (44). The elevation in Ppard and the reduction in Pparg in mammary tumors, in the current study, support the concept of a competitive mechanism between the promotive effect of Ppard and the suppressive effect of Pparg in mammary carcinogenesis (44).

The current study showed that TRF reduced elevated expression of Hmgcr, Srebp1, Fads2, and Ppard in mammary tumors. These reductions provide direct evidence 
that TRF may downregulate the altered lipid metabolism in MMTV-PyMT mammary tumors. However, these findings are inconsistent with the lack of differences in lipid metabolites in mammary tumors between the TRF and the HFD groups. It suggests that the liver may provide sufficient amounts of lipid substrates to mammary tumor cells or that the tumor cells may use dietary lipids as substrates directly. This warrants further investigation.

The concentrations of 3-hydroxybutyric acid in mammary tumors were $56 \%$ lower in the TRF group than in the HFD group. 3-Hydroxybutyric acid is a main ketone body generated from excessive acetyl-CoA production resulting from hepatic $\beta$-oxidation; it is an indicator of excessive lipid oxidation and potential mitochondrial dysfunction $(45,46)$. Previous studies have shown that TRF elevates 3-hydroxybutyric acid in plasma $(47,48)$. Decrements of this ketone body in mammary tumors by TRF suggest an increase in utilization of this energy source by the tumor cells. Because 3-hydroxybutyric acid is ordinarily utilized in fasting conditions in lieu of glucose, reduced 3hydroxybutyric acid in mammary tumors suggest a shift in substrate utilization that may contribute to the observed mitigation of mammary tumorigenesis by the TRF (19).

We found that TRF mitigates HFD-enhanced mammary tumorigenesis, evidenced by a reduction in tumor progression rate in MMTV-PyMT mice (19). However, there were no significant differences in most of the metabolites identified, except 3-hydroxybutyric acid, when TRF was compared to the HFD. These findings suggest a probability that the protection of TRF against mammary tumorigenesis is likely through its action on the host. In fact, it has been well documented that reduction in body adiposity and inflammation and improvement in insulin sensitivity are characteristics of TRF in rodents (12-14). We reported that consumption of a HFD alters lipidomic profiles, including triacylglycerol, phosphatidylethanolamine, and phosphatidylcholine, in primary tumors from a mouse model of Lewis lung carcinoma (49). Given the fact that TRF reduced the expression of Hmgcr, Srebp1, Fads2, and Ppard in mammary tumors, the effects of TRF on lipidome in mammary tumors certainly warrant further investigation.

A limitation of this study is that we were not able to perform plasma metabolomics from each dietary group, which made us unable to compare metabolomic differences between plasma and mammary tumors by TRF in parallel. This is certainly a goal of future studies to understand roles of TRF in mammary tumorigenesis. The other limitation is that we identified only 94 metabolites by using the GC-TOFMS. Thus, there is a possibility that other signaling pathways might be altered by MMTV-PyMT tumorigenesis or by diets but were not captured by the GC-TOF-MS. This should be considered when interpreting results from this study.

In summary, the current study showed an accelerated, disordered metabolism in mammary tumors, evidenced by disrupted metabolic profiles and expression of genes encoding proteins involved in lipid metabolism in mammary tumors from MMTV-PyMT mice compared to mammary glands from wild-type controls. There were no significant differences in mammary tumor metabolic profiles between the TRF and the HFD groups. These findings suggest that the protection of TRF on mammary tumorigenesis (19) is likely through its action on the host, evidenced by reductions in body fat mass and inflammation and improvement in insulin sensitivity and metabolism in rodents receiving TRF (12-14). However, it does not exclude the possibility that TRF may alter lipid metabolism in mammary tumors, evidenced by a reduction in expression of Hmgcr, Srebp1, Fads2, and Ppard in mammary tumors of MMTV-PyMT mice.

\section{Conflicts of Interest}

The Authors have declared that no competing interests exist regarding this study.

\section{Authors' Contributions}

LY and SS conceived and designed the study, performed the experiments, and collected data. BMR, MJP, and MRB contributed to data analysis and interpretation of results. All Authors contributed to the preparation, review, and revision of the manuscript. All Authors agreed to be accountable for the content of the work.

\section{Acknowledgements}

The Authors gratefully acknowledge the assistance of the following staff of the Grand Forks Human Nutrition Research Center: Lana DeMars and Shawn Krueger for technical support and vivarium staff for preparing experimental diets and providing high-quality animal care.

\section{Funding}

This work was funded by the USDA Agricultural Research Service Projects \#3062-51000-050-00D and \#3062-51000-056-00D (LY) and \#3062-53000-001-00D (MJP).

\section{References}

1 Bray F, Ferlay J, Soerjomataram I, Siegel RL, Torre LA and Jemal A: Global cancer statistics 2018: GLOBOCAN estimates of incidence and mortality worldwide for 36 cancers in 185 countries. CA Cancer J Clin 68: 394-424, 2018. PMID: 30207593. DOI: $10.3322 /$ caac. 21492

2 Giskeodegard GF, Grinde MT, Sitter B, Axelson DE, Lundgren S, Fjosne HE, Dahl S, Gribbestad IS and Bathen TF: Multivariate modeling and prediction of breast cancer prognostic factors using MR metabolomics. J Proteome Res 9: 972-979, 2010. PMID: 19994911. DOI: 10.1021/pr9008783

3 Sitter B, Bathen TF, Singstad TE, Fjosne HE, Lundgren S, Halgunset J and Gribbestad IS: Quantification of metabolites in breast cancer patients with different clinical prognosis using HR 
MAS MR spectroscopy. NMR Biomed 23: 424-431, 2010. PMID: 20101607. DOI: 10.1002/nbm.1478

4 Tang X, Lin CC, Spasojevic I, Iversen ES, Chi JT and Marks JR: A joint analysis of metabolomics and genetics of breast cancer. Breast Cancer Res 16: 415, 2014. PMID: 25091696. DOI: $10.1186 / \mathrm{s} 13058-014-0415-9$

5 Picon-Ruiz M, Morata-Tarifa C, Valle-Goffin JJ, Friedman ER and Slingerland JM: Obesity and adverse breast cancer risk and outcome: Mechanistic insights and strategies for intervention. CA Cancer J Clin, 2017. PMID: 28763097. DOI: 10.3322/caac.21405

6 Rohan TE, Heo M, Choi L, Datta M, Freudenheim JL, Kamensky V, Ochs-Balcom HM, Qi L, Thomson CA, Vitolins MZ, Wassertheil-Smoller S and Kabat GC: Body fat and breast cancer risk in postmenopausal women: a longitudinal study. J Cancer Epidemiol 2013: 754815, 2013. PMID: 23690776. DOI: 10.1155/2013/754815

7 Bae SA, Fang MZ, Rustgi V, Zarbl H and Androulakis IP: At the interface of lifestyle, behavior, and circadian rhythms: metabolic implications. Front Nutr 6: 132, 2019. PMID: 31555652. DOI: 10.3389/fnut.2019.00132

8 Maury E and Brichard SM: Adipokine dysregulation, adipose tissue inflammation and metabolic syndrome. Mol Cell Endocrinol 314: 1-16, 2010. PMID: 19682539. DOI: 10.1016/j.mce.2009.07.031

9 Branecky KL, Niswender KD and Pendergast JS: Disruption of daily rhythms by high-fat diet is reversible. PLoS One 10: e0137970, 2015. PMID: 26366733. DOI: 10.1371/journal.pone.0137970

10 Zarrinpar A, Chaix A and Panda S: Daily eating patterns and their impact on health and disease. Trends Endocrinol Metab 27: 69-83, 2016. PMID: 26706567. DOI: 10.1016/j.tem.2015.11.007

11 Arble DM, Bass J, Laposky AD, Vitaterna MH and Turek FW: Circadian timing of food intake contributes to weight gain. Obesity 17: 2100-2102, 2009. PMID: 19730426. DOI: 10.1038/oby.2009.264

12 Sundaram S and Yan L: Time-restricted feeding reduces adiposity in mice fed a high-fat diet. Nutr Res 36: 603-611, 2016. PMID: 27188906. DOI: 10.1016/j.nutres.2016.02.005

13 Hatori M, Vollmers C, Zarrinpar A, DiTacchio L, Bushong EA, Gill S, Leblanc M, Chaix A, Joens M, Fitzpatrick JA, Ellisman MH and Panda S: Time-restricted feeding without reducing caloric intake prevents metabolic diseases in mice fed a high-fat diet. Cell Metab 15: 848-860, 2012. PMID: 22608008. DOI: 10.1016/j.cmet.2012.04.019

14 Chaix A, Lin T, Le HD, Chang MW and Panda S: Timerestricted feeding prevents obesity and metabolic syndrome in mice lacking a circadian clock. Cell Metab 29: 303-319 e304, 2019. PMID: 30174302. DOI: 10.1016/j.cmet.2018.08.004

15 Guy CT, Cardiff RD and Muller WJ: Induction of mammary tumors by expression of polyomavirus middle $\mathrm{T}$ oncogene: a transgenic mouse model for metastatic disease. Mol Cell Biol 12: 954-961, 1992. PMID: 1312220. DOI: 10.1128/MCB.12.3.954

16 Lin EY, Jones JG, Li P, Zhu L, Whitney KD, Muller WJ and Pollard JW: Progression to malignancy in the polyoma middle $\mathrm{T}$ oncoprotein mouse breast cancer model provides a reliable model for human diseases. Am J Pathol 163: 2113-2126, 2003. PMID: 14578209. DOI: 10.1016/S0002-9440(10)63568-7

17 Herschkowitz JI, Simin K, Weigman VJ, Mikaelian I, Usary J, $\mathrm{Hu} \mathrm{Z}$, Rasmussen KE, Jones LP, Assefnia S, Chandrasekharan S, Backlund MG, Yin Y, Khramtsov AI, Bastein R, Quackenbush J, Glazer RI, Brown PH, Green JE, Kopelovich L, Furth PA,
Palazzo JP, Olopade OI, Bernard PS, Churchill GA, Van Dyke $\mathrm{T}$ and Perou CM: Identification of conserved gene expression features between murine mammary carcinoma models and human breast tumors. Genome Biol 8: R76, 2007. PMID: 17493263. DOI: $10.1186 / \mathrm{gb}-2007-8-5-\mathrm{r} 76$

18 Maglione JE, Moghanaki D, Young LJ, Manner CK, Ellies LG, Joseph SO, Nicholson B, Cardiff RD and MacLeod CL: Transgenic polyoma middle-T mice model premalignant mammary disease. Cancer Res 61: 8298-8305, 2001. PMID: 11719463.

19 Sundaram S and Yan L: Time-restricted feeding mitigates highfat diet-enhanced mammary tumorigenesis in MMTV-PyMT mice. Nutr Res 59: 72-79, 2018. PMID: 30442235. DOI: 10.1016/j.nutres.2018.07.014

20 Reeves PG, Nielsen FH and Fahey GCJ: AIN-93 purified diets for laboratory rodents: final report of the American Institute of Nutrition Ad Hoc Writing Committee on the reformulation of the AIN-76A rodent diet. J Nutr 123: 1939-1951, 1993. PMID: 8229312. DOI: $10.1093 / \mathrm{jn} / 123.11 .1939$

21 Institute for Laboratory Animal Research: Guide for the care and use of laboratory animals. Washington, D.C.: National Academies Press, 2011.

22 Fiehn O, Garvey WT, Newman JW, Lok KH, Hoppel CL and Adams SH: Plasma metabolomic profiles reflective of glucose homeostasis in non-diabetic and type 2 diabetic obese AfricanAmerican women. PLoS One 5: e15234, 2010. PMID: 21170321. DOI: 10.1371/journal.pone.0015234

23 Piccolo BD, Keim NL, Fiehn O, Adams SH, Van Loan MD and Newman JW: Habitual physical activity and plasma metabolomic patterns distinguish individuals with low vs. high weight loss during controlled energy restriction. J Nutr 145: 681690, 2015. PMID: 25833772. DOI: 10.3945/jn.114.201574

24 Fiehn O, Wohlgemuth G and Scholz C: Setup and Annotation of Metabolomic Experiments by Integrating Biological and Mass Spectrometric Metadata. In: Data Integration in the Life Sciences. Ludäscher B, Raschid L (eds.). Berlin, Heidelberg: Springer, pp. 224-239, 2005.

25 Livak KJ and Schmittgen TD: Analysis of relative gene expression data using real-time quantitative PCR and the 2(Delta Delta C(T)) method. Methods 25: 402-408, 2001. PMID: 11846609. DOI: $10.1006 /$ meth.2001.1262

$26 \mathrm{Xia} \mathrm{J}$ and Wishart DS: Using MetaboAnalyst 3.0 for comprehensive metabolomics data analysis. Curr Protoc Bioinformatics 55: 1410 11-14 10 91, 2016. PMID: 27603023. DOI: $10.1002 / \mathrm{cpbi} .11$

27 van den Berg RA, Hoefsloot HCJ, Westerhuis JA, Smilde AK and van der Werf MJ: Centering, scaling, and transformations: improving the biological information content of metabolomics data. BMC Genomics 7: 142, 2006. PMID: 16762068. DOI: 10.1186/1471-2164-7-142

28 Sundaram S and Yan L: High-fat diet enhances mammary tumorigenesis and pulmonary metastasis and alters inflammatory and angiogenic profiles in MMTV-PyMT mice. Anticancer Res 36: 6279-6287, 2016. PMID: 27919947. DOI: 10.21873/ anticanres. 11223

29 Swinnen JV, Vanderhoydonc F, Elgamal AA, Eelen M, Vercaeren I, Joniau S, Van Poppel H, Baert L, Goossens K, Heyns W and Verhoeven G: Selective activation of the fatty acid synthesis pathway in human prostate cancer. Int J Cancer 88: 176-179, 2000. PMID: 11004665. DOI: 10.1002/1097-0215(20001015) $88: 2<176::$ aid-ijc5>3.0.co;2-3 
30 Rashid A, Pizer ES, Moga M, Milgraum LZ, Zahurak M, Pasternack GR, Kuhajda FP and Hamilton SR: Elevated expression of fatty acid synthase and fatty acid synthetic activity in colorectal neoplasia. Am J Pathol 150: 201-208, 1997. PMID: 9006336.

$31 \mathrm{Zhu} \mathrm{L}$ and Bakovic M: Breast cancer cells adapt to metabolic stress by increasing ethanolamine phospholipid synthesis and CTP:ethanolaminephosphate cytidylyltransferase-Pcyt2 activity. Biochem Cell Biol 90: 188-199, 2012. PMID: 22339418. DOI: 10.1139/o11-081

32 Shah T, Krishnamachary B, Wildes F, Wijnen JP, Glunde K and Bhujwalla ZM: Molecular causes of elevated phosphoethanolamine in breast and pancreatic cancer cells. NMR Biomed 31: e3936, 2018. PMID: 29928787. DOI: 10.1002/nbm.3936

33 Krikken E, van der Kemp WJM, van Diest PJ, van Dalen T, van Laarhoven HWM, Luijten PR, Klomp DWJ and Wijnen JP: Early detection of changes in phospholipid metabolism during neoadjuvant chemotherapy in breast cancer patients using phosphorus magnetic resonance spectroscopy at 7T. NMR Biomed 32: e4086, 2019. PMID: 30924571. DOI: 10.1002/nbm.4086

34 Budczies J, Denkert C, Muller BM, Brockmoller SF, Klauschen F, Gyorffy B, Dietel M, Richter-Ehrenstein C, Marten U, Salek RM, Griffin JL, Hilvo M, Oresic M, Wohlgemuth G and Fiehn $\mathrm{O}$ : Remodeling of central metabolism in invasive breast cancer compared to normal breast tissue - a GC-TOFMS based metabolomics study. BMC Genomics 13: 334, 2012. PMID: 22823888. DOI: 10.1186/1471-2164-13-334

35 Liu J, Xu A, Lam KS, Wong NS, Chen J, Shepherd PR and Wang Y: Cholesterol-induced mammary tumorigenesis is enhanced by adiponectin deficiency: role of LDL receptor upregulation. Oncotarget 4: 1804-1818, 2013. PMID: 24113220. DOI: $10.18632 /$ oncotarget.1364

36 Llaverias G, Danilo C, Mercier I, Daumer K, Capozza F, Williams TM, Sotgia F, Lisanti MP and Frank PG: Role of cholesterol in the development and progression of breast cancer. Am J Pathol 178: 402-412, 2011. PMID: 21224077. DOI: 10.1016/j.ajpath.2010.11.005

37 Perez-Escuredo J, Dadhich RK, Dhup S, Cacace A, Van Hee VF, De Saedeleer CJ, Sboarina M, Rodriguez F, Fontenille MJ, Brisson L, Porporato PE and Sonveaux P: Lactate promotes glutamine uptake and metabolism in oxidative cancer cells. Cell Cycle 15: 72-83, 2016. PMID: 26636483. DOI: 10.1080/15384101.2015.1120930

38 Giskeodegard GF, Lundgren S, Sitter B, Fjosne HE, Postma G, Buydens LM, Gribbestad IS and Bathen TF: Lactate and glycine-potential MR biomarkers of prognosis in estrogen receptor-positive breast cancers. NMR Biomed 25: 1271-1279, 2012. PMID: 22407957. DOI: $10.1002 / \mathrm{nbm} .2798$

39 Mayers JR, Wu C, Clish CB, Kraft P, Torrence ME, Fiske BP, Yuan C, Bao Y, Townsend MK, Tworoger SS, Davidson SM, Papagiannakopoulos T, Yang A, Dayton TL, Ogino S, Stampfer MJ, Giovannucci EL, Qian ZR, Rubinson DA, Ma J, Sesso HD, Gaziano JM, Cochrane BB, Liu S, Wactawski-Wende J, Manson JE, Pollak MN, Kimmelman AC, Souza A, Pierce K, Wang TJ, Gerszten RE, Fuchs CS, Vander Heiden MG and Wolpin BM: Elevation of circulating branched-chain amino acids is an early event in human pancreatic adenocarcinoma development. Nat Med 20: 1193-1198, 2014. PMID: 25261994. DOI: 10.1038/nm.3686
40 Maddocks ODK, Athineos D, Cheung EC, Lee P, Zhang T, van den Broek NJF, Mackay GM, Labuschagne CF, Gay D, Kruiswijk F, Blagih J, Vincent DF, Campbell KJ, Ceteci F, Sansom OJ, Blyth K and Vousden KH: Modulating the therapeutic response of tumours to dietary serine and glycine starvation. Nature 544: 372-376, 2017. PMID: 28425994. DOI: 10.1038 /nature22056

41 Warburg O: On the origin of cancer cells. Science 123: 309-314, 1956. PMID: 13298683. DOI: 10.1126/science.123.3191.309

42 Guasch-Ferre M, Hruby A, Toledo E, Clish CB, MartinezGonzalez MA, Salas-Salvado J and Hu FB: Metabolomics in prediabetes and diabetes: a systematic review and meta-analysis. Diabetes Care 39: 833-846, 2016. PMID: 27208380. DOI: $10.2337 / \mathrm{dc} 15-2251$

43 Wagner KD and Wagner N: Peroxisome proliferator-activated receptor beta/delta (PPARbeta/delta) acts as regulator of metabolism linked to multiple cellular functions. Pharmacol Ther 125: 423-435, 2010. PMID: 20026355. DOI: 10.1016/ j.pharmthera.2009.12.001

44 Yin Y, Russell RG, Dettin LE, Bai R, Wei ZL, Kozikowski AP, Kopelovich L and Glazer RI: Peroxisome proliferator-activated receptor delta and gamma agonists differentially alter tumor differentiation and progression during mammary carcinogenesis. Cancer Res 65: 3950-3957, 2005. PMID: 15867396. DOI: 10.1158/0008-5472.CAN-04-3990

45 Dueregger A, Schopf B, Eder T, Hofer J, Gnaiger E, Aufinger A, Kenner L, Perktold B, Ramoner R, Klocker H and Eder IE: Differential utilization of dietary fatty acids in benign and malignant cells of the prostate. PLoS One 10: e0135704, 2015. PMID: 26285134. DOI: 10.1371/journal.pone.0135704

46 Fukao T, Mitchell G, Sass JO, Hori T, Orii K and Aoyama Y: Ketone body metabolism and its defects. J Inherit Metab Dis 37: 541-551, 2014. PMID: 24706027. DOI: 10.1007/s10545-0149704-9

47 Yan L, Rust BM and Picklo MJ: Plasma metabolomic changes in mice with time-restricted feeding-attenuated spontaneous metastasis of lewis lung carcinoma. Anticancer Res 40: 18331841, 2020. PMID: 32234871. DOI: 10.21873/anticanres.14137

48 Miyauchi T, Uchida Y, Kadono K, Hirao H, Kawasoe J, Watanabe T, Ueda S, Okajima H, Terajima $H$ and Uemoto S: Up-regulation of FOXO1 and reduced inflammation by betahydroxybutyric acid are essential diet restriction benefits against liver injury. Proc Natl Acad Sci U S A 116: 13533-13542, 2019. PMID: 31196960 . DOI: 10.1073/pnas.1820282116

49 Sundaram S, Zacek P, Bukowski MR, Mehus AA, Yan L and Picklo MJ: Lipidomic impacts of an obesogenic diet upon lewis lung carcinoma in mice. Front Oncol 8: 134, 2018. PMID: 29868466. DOI: $10.3389 /$ fonc. 2018.00134
Received May 2, 2020

Revised May 16, 2020

Accepted May 20, 2020 